\title{
Implementing a Progressive Consumption Tax: Advantages of Adopting the VAT Credit-Method System
}

Itai Grinberg

Georgetown University Law Center, itai.grinberg@law.georgetown.edu

This paper can be downloaded free of charge from:

https://scholarship.law.georgetown.edu/facpub/1606

http://ssrn.com/abstract=2824444

59 Nat'l Tax J. 929-954 (2006)

This open-access article is brought to you by the Georgetown Law Library. Posted with permission of the author. Follow this and additional works at: https://scholarship.law.georgetown.edu/facpub

Part of the Tax Law Commons 


\section{Implementing a Progressive Consumption Tax: Advantages of Adopting the VAT Credit-Method System}

\begin{abstract}
A credit-method value-added tax, a payroll tax, and a business-level wage subsidy can approximate the economic and distributional consequences of a subtraction-method X-tax. Such a credit-method progressive consumption tax has administrative advantages as compared to a subtraction-method progressive consumption tax, once certain political factors are taken into account. Further, unlike a subtraction-method system, a creditmethod progressive consumption tax could easily interact with other tax systems around the world and comply with World Trade Organization rules without sacrificing best practice VAT design features that allow for effective enforcement.
\end{abstract}

\section{INTRODUCTION}

$\mathrm{O}$ ne of the most basic questions in the perennial debate on fundamental tax reform in the United States is whether the federal government should tax income, consumption, or both. Advocates of consumption taxes variously hope such a move would simplify the tax code, improve economic efficiency, encourage savings and investment, and help solve the nation's long-term fiscal challenges by providing a stable source of funding for growing entitlement programs. Some proposals would use a consumption tax to replace the income tax, while others would reduce income tax rates and raise the income threshold for income tax liability.

Numerous progressive consumption tax proposals have received attention in academic and political circles. Among the most well-known proposals are the Flat Tax, popularized by presidential candidate Steve Forbes, and the X-tax, a progressive rate variation developed by the late David Bradford that uses the same structure as the Flat Tax. Most recently, the President's Advisory Panel on Federal Tax Reform (Tax Reform Panel) based the consumption tax portion of its "Growth and Investment Tax" (GIT) proposal on the X-tax structure. ${ }^{1}$

Also of note are "consumption-type personal income tax" proposals (Andrews, 1974; McCaffrey, 2002). This type of proposal has received less attention since the failure of the "USA Tax," a piece of proposed legislation based on this model, in 1995.
Vol. LIX, No. 4

December 2006 
The Flat Tax and the X-tax both modify a "subtraction-method" value-added tax (VAT) in a manner that makes the distribution of the burden of a VAT more progressive. Unlike the Flat Tax and the X-tax, VATs are almost always implemented using a "credit method." Credit-method VATs are a successful mainstay of fiscal systems in over 130 countries around the world, including every Organisation for Economic Co-operation and Development (OECD) country besides the United States. On average, VATs provide about 18 percent of total tax revenues in OECD countries, making them an important source of government revenue. ${ }^{2}$

The "subtraction method" and the "credit method" are two alternative methods for calculating VAT liability. While the credit method is used ubiquitously, Japan is the only developed economy that utilizes some subtraction-method features to impose a VAT. No progressive subtraction-method VAT has ever been put into practice in any country.

Many prior papers have analyzed progressive subtraction-method consumption tax proposals. Little discussion, however, has focused on whether a progressive consumption tax that is economically similar to the Flat Tax or the X-tax (referred to together in this article as a "subtraction-method X-tax") could be implemented using the credit method. ${ }^{3}$ This article suggests that both the economic and distributional consequences of these tax systems could be approximated using a different tax structure based on a credit-method system. A "credit-method X-tax," would consist of three formally separate components. First, the government would impose a standard credit-method VAT. Second, it would impose a separate wage tax. Third, it would provide incentive payments to businesses in connection with hiring U.S. workers.

This article argues that a credit-method system of this sort has two key advantages over the subtraction-method X-tax that academic discussion has focused upon up to this point. First, the ability to adopt best practices from credit-method systems in use around the world provides the credit method with substantial practical advantages. It would be politically difficult to adapt certain best practices associated with credit-method VATs to a subtraction-method system. Second, a credit-method X-tax would easily interact with other tax systems around the world, whereas a subtraction-method X-tax would not. A subtraction-method X-tax cannot be implemented on a "destination basis" with respect to cross-border transactions and remain in compliance with World Trade Organization (WTO) rules. Being judged WTO non-compliant would allow trading partners to impose countervailing sanctions against U.S. exports and companies. Such sanctions could be of a magnitude sufficient to make the system impossible to implement without renegotiating the framework for the world's international trade regime. On the other hand, an X-tax that is implemented on an "origin basis," the alternative to a destination basis, may be difficult or even impossible to enforce. Thus, a progressive credit-method consumption tax utilizing a business-level wage subsidy would be administrable and enforceable, whereas a subtraction-method X-tax may not be.

The article first describes the features of a VAT, a Flat Tax, and the X-tax as developed by David Bradford, and highlights the similarities and differences between implementing a consumption tax using

\footnotetext{
See Owens (2006) for a detailed discussion of revenue sources in OECD countries.

3 Weisbach (2003) considers a progressive credit-method structure before concluding that with the same information collection, at a conceptual level the subtraction method and the credit method are equivalent. See footnote 15 and accompanying text for further discussion.
} 
the credit method or the subtraction method. The article then focuses on certain potential administrative advantages of a credit-method VAT relative to a subtraction-method VAT. Third, the article explains the WTO rules regarding cross-border taxation, illustrates why a destination-basis, subtraction-method X-tax would not withstand WTO scrutiny, and describes administration and enforcement problems that would arise were the subtraction-method X-tax to be imposed on an origin basis instead, in order to comply with WTO rules. The article then shows how a VAT, a payroll tax, and a business-level wage subsidy could be combined to approximate the economic and distributional consequences of a subtraction-method X-tax. This "creditmethod X-tax" is formally WTO-compliant if imposed on a destination-basis and thereby should avoid the administration and enforcement problems that would arise in an origin-basis X-tax. Finally, the article notes that distributional programs other than a business-level wage subsidy, such as cash payments to individuals, a payroll tax rebate, or other demogrants could be used to achieve distributional results that are similar to the credit-method $X$-tax. I conclude that even if policymakers were to desire the economic and distributional result entailed by variants of a subtraction-method X-tax, it would be best to accomplish those goals with a credit-method VAT, along with other tax and spending tools, rather than by implementing a subtraction-method $\mathrm{X}$-tax.

\section{INTRODUCTION TO CONSUMPTION TAXES}

A variety of tax structures can be used to tax the value of goods and services consumed by taxpayers. In the United States, the most familiar consumption tax is the retail sales tax (RST) used by most of the states. A conceptually pure RST would be imposed whenever a household purchased any good or service for the purpose of consumption. However, real-world RSTs often are imposed on a relatively narrow group of goods and services and are prone to evasion. ${ }^{4}$ RSTs also tend to "cascade," which is to say that some goods are double-taxed because businesses pay RST on goods or services they purchase as inputs for their business processes, and then those inputs are taxed a second time as part of the sale of the final good or service.

The VAT is an RST that is collected in smaller increments throughout the production process. Relative to an RST, the VAT reduces evasion, improves enforcement, is easier to impose on a broader base of goods and services, and systematically avoids the "cascading" problem. ${ }^{5}$

The Flat Tax and the X-tax are consumption taxes that collect the portion of the value added to a product attributable to labor at the individual level using a graduated rate structure. These graduated rates tax consumption progressively. Both the Flat Tax and the X-tax are intellectual cousins of the VAT, because they modify a VAT structure by using the subtraction-method and graduated rates for the portion of the value-added attributable to labor.

\section{Credit-Method VAT}

In a credit-method VAT, registered businesses assess tax on the goods and services they sell each time they make a sale to either a business or a consumer. Registered businesses are then permitted

\footnotetext{
4 Keen and Smith (2006) review what is known about VAT evasion and fraud in a companion piece to this forum article.

5 Mikesell (2005) and McLure (1998) offer discussions of the narrowness of RST bases and their susceptibility to evasion.
} 
to reduce the amount of VAT they must remit to the government by a credit equal to the amount of VAT paid to other registered businesses in purchasing business inputs (goods, services, plant and equipment, etc.). The credit eliminates the tax on goods and services used by a business, but leaves in place the tax on sales to final consumers. This mechanism ensures that the consumption of all goods and services subject to the VAT will be taxed once, but only once, at the consumer level.

The amount of VAT credit available to a business to offset VAT liability is generally determined based on printed invoices received by a purchasing business from a selling business. These invoices detail the amount of VAT collected on a given sale. A VAT-paying business subtracts the amount of VAT paid, as represented on invoices, from the amount of VAT that otherwise would be due on its sales. In a well-functioning VAT, a loss-making business with more input credits than VAT liability can obtain a refund for excess VAT paid. After applying input credits, a business's final VAT liability is equivalent to a tax on the "value added" by that business; that is, the sales price of its outputs less the purchase price of its non-labor inputs.

Example 1 (Table 1) illustrates how the VAT collects the same amount of tax as an ideal retail sales tax. A small brewer buys barley and hops from a farmer and uses them to produce kegs of beer for sale to retailers. The brewer buys barley and hops from the farmer at a cost of $\$ 30$ per keg before tax. The brewer sells each keg for $\$ 70$ before tax. The retailer sells a keg for $\$ 100$ before tax. In an ideal RST, only the sale by the retailer to consumers would be taxed. If the RST rate were 30 percent, $\$ 30$ of tax would be due on the sale of a $\$ 100$ keg.

A30 percent VAT added to each transaction in the brewing and distribution process collects the same amount of revenue as a non-cascading RST (charged only to final consumers). Because the VAT is charged on all sales of goods and services, the farmer collects 30 percent VAT on her sales of barley and hops, charging the brewer $\$ 9$ of tax on each $\$ 30$ of sales. The farmer remits the \$9 of VAT to the government. Similarly, the brewer charges the retailer $\$ 91(\$ 70+\$ 21$ of VAT) per keg. However, instead of sending all \$21 of VAT to the government, the brewer subtracts the $\$ 9$ of VAT paid by the brewer to the farmer from the \$21 collected in VAT, and remits $\$ 12$ to the government per keg sold. Similarly, instead of sending \$30 per keg sold to the government, the retailer subtracts the $\$ 21$ of VAT paid by the retailer to the brewer from the $\$ 30$ collected in VAT, and remits $\$ 9$ to the government per keg sold. The tax authority receives $\$ 30$ in total $-\$ 9$ from the farmer, \$12 from the brewer, and

TABLE 1

EXAMPLE 1: VAT

\begin{tabular}{|c|c|c|c|c|}
\hline Economic Activity & Farmer & Brewer & Retailer & Total \\
\hline \multicolumn{5}{|l|}{ Basic transactions } \\
\hline 1. Sales & $\$ 30$ & $\$ 70$ & $\$ 100$ & \\
\hline 2. Purchases & $\$ 0$ & $\$ 30$ & $\$ 70$ & \\
\hline 3. Labor & $\$ 20$ & $\$ 20$ & $\$ 26$ & \\
\hline 4. Value added (sales - purchases) & $\$ 30$ & $\$ 40$ & $\$ 30$ & $\$ 100$ \\
\hline \multicolumn{5}{|l|}{ Credit-Method VAT } \\
\hline 5. Tax on sales $(30 \%$ of line 1$)$ & $\$ 9$ & $\$ 21$ & $\$ 30$ & \\
\hline 6. Less: input tax on purchases & $\$ 0$ & $\$ 9$ & $\$ 21$ & \\
\hline 7. Net VAT liability & $\$ 9$ & $\$ 12$ & $\$ 9$ & $\$ 30$ \\
\hline \multicolumn{5}{|l|}{ Subtraction-Method VAT } \\
\hline $\begin{array}{l}\text { 8. VAT liability } \\
(30 \% \text { of line } 4)\end{array}$ & $\$ 9$ & $\$ 12$ & $\$ 9$ & $\$ 30$ \\
\hline
\end{tabular}


$\$ 9$ from the retailer. The VAT and the RST collect equivalent amounts of revenue, and from the consumer's perspective the taxes look identical.

Credit-method VAT liability is generally calculated from accounts for a taxable period (generally monthly, bi-monthly, or quarterly). Aggregate input tax paid is subtracted from aggregate tax liability on all taxable sales for the taxable period. Notwithstanding the fact that the credit-method VAT is often referred to as a "transaction-based" tax (because conceptually the tax is assessed on each individual transaction subject to the VAT), VAT liability and VAT credits are not matched for each individual item sold.

\section{Subtraction-Method VAT}

The most important formal difference between the subtraction-method VAT and the credit-method VAT is that the former does not use credits. ${ }^{6}$ Tax paid is not subtracted from tax liability, as in the credit method. Instead, businesses subtract the total value of their purchases from other businesses subject to VAT from the total value of their sales and then multiply by the VAT rate to determine their tax liability. Thus, the subtraction method is sometimes described as being "account-based" rather than "transaction-based."

Another difference between subtraction-method and credit-method VATs is that the former may not use invoices to verify whether a taxpayer actually paid VAT on the purchases from other businesses that the taxpayer claims as deductions. Regardless of whether invoices are used, however, technically sophisticated subtraction-method VAT proposals should not allow taxpayers to deduct the cost of purchases from businesses that do not collect VAT - at least in the case of purchases made from domestic businesses (Hufbauer and Grieco, 2005; Tax Reform Panel, 2005).

Setting aside any administration and enforcement considerations, and assuming that all purchases are made from other VAT-paying businesses, the distinctions described above make no difference in terms of revenue collected. Exactly the same amount of tax should be levied at each stage in the production process and paid by each firm under the subtractionmethod VAT as under the credit-method VAT. The amounts collected under the two taxes are identical because the tax value of subtracting purchased inputs from the tax base is arithmetically identical to a credit for all previous VAT paid at the same tax rate on those inputs.

\section{The Japanese Hybrid VAT}

While the credit-method VAT is used all around the world, no major developed economy imposes a subtraction-method VAT. The Japanese VAT is sometimes described as a subtraction-method tax in the U.S. tax literature, but is more of a hybrid of the subtraction and credit methods. ${ }^{8}$ The Japanese VAT resembles a prototypical subtraction-method VAT in the sense that Japanese VAT taxpayers are allowed to derive the amount of credit for VAT paid to which they are entitled based on total purchases from domestic entities, instead of adding up amounts shown on credit-method invoices. Furthermore, the Japanese VAT uses an annual accounting period. ${ }^{9}$ Accounting periods are signifi-

\footnotetext{
6 The subtraction-method VAT is also sometimes called a "business transfer tax."

7 For a discussion of the distinction between "account-based" and "transaction-based" taxes in the context of border adjustability, see Summers (1996).

8 See Schenk (1995), Thuronyi (2003) and Japanese Ministry of Finance (2005) for information on how the Japanese VAT is run.

9 Certain businesses may elect to pay VAT quarterly, including exporters eligible for refunds.
} 
cantly shorter in credit-method VATs used in the OECD.

As in credit-method VATs, the Japanese allow their VAT taxpayers to deduct consumption tax paid over a taxable period from consumption tax due. In this respect, the Japanese use the credit method. The Japanese VAT also includes special rules for mid-sized businesses that allow them to pay presumptive VAT liability rather than VAT calculated based on actual sales and input tax paid. As a result, the Japanese VAT allows subtraction-method VAT deductions (the equivalent of credit-method input credits) for some presumptive purchases that may not have been made or on which VAT may not have been assessed. ${ }^{10}$ In this regard, the "real world" Japanese VAT does not comport with the theoretical requirement that would limit taxpayers in a hypothetical subtraction-method VAT to deducting the cost of purchases from businesses that themselves collect VAT.

\section{Single-Rate Flat Tax}

The "Flat Tax" is based on a subtraction-method VAT, but adds workers to the collection process. Robert Hall and Alvin Rabushka, two Stanford economists, first proposed the Flat Tax (Hall and Rabushka, 1995). ${ }^{11}$ Like a subtraction-method VAT, the starting point for calculating a business' Flat Tax liability is the difference between the value of sales of goods and services and the value of purchases (including goods, services, plant, and equipment) from other businesses subject to the Flat Tax. However, in contrast to a VAT, businesses are also permitted to subtract amounts paid to employees as compensation. ${ }^{12}$

The Flat Tax then imposes an employeelevel tax on wages. Amounts removed from the business Flat Tax base via the wage deduction are thereby added back to the overall tax base by taxing employees. In this way, tax on the portion of a business' value-added attributable to labor is collected from workers instead of businesses. In the case of a Flat Tax with identical rates at the business and employee level, and no zero-bracket amount, the total amount of revenue collected would be equivalent to the revenue collected by a VAT imposed at the same rate. The most important conceptual difference between the VAT and the Flat Tax is, therefore, the point of collection of the tax. Unlike a VAT, the Flat Tax requires both businesses and individuals to file and pay taxes. ${ }^{13}$

The Flat Tax as proposed by Hall and Rabushka includes a zero-bracket amount below which taxpayers pay no tax on their wages. In this sense, the Flat Tax is not "flat" at all-rather there are two rates: zero and another positive rate. The zero bracket makes the Flat Tax progressive, unlike a standard VAT.

10 Businesses with annual taxable sales of less than $¥ 50$ million can choose to calculate their VAT input credits by multiplying tax liability on sales by a fixed percentage determined based on a statutorily prescribed business classification system (Japanese Ministry of Finance, 2005).

11 Former presidential candidate Steve Forbes and former House Majority Leader Dick Armey first popularized the proposal.

12 To prevent leakage from the consumption tax base, the Flat Tax should limit the business-level deduction for compensation to compensation that is subject to U.S. tax at the individual level. Hall and Rabushka (1995) do not, however, address this issue in their writings about the Flat Tax.

13 The Flat Tax also differs from a VAT in that it would provide a carryforward for losses. The carryforward would grow at a market rate of interest (Hall, 2005). In contrast, losses are refunded under most credit-method VATs (Ebrill, Keen, Bodin, and Summers, 2001). The policy of carrying losses forward rather than refunding them is in part a consequence of the fact that many more businesses would have input credits that exceed their Flat Tax liability than is the case in a VAT, because under a VAT there is no input credit (deduction) for wages paid. 


\section{Subtraction-Method X-tax}

The X-tax as conceived by David Bradford increases the progressivity of a Flat Tax-like structure (see, for example, Bradford $(1996,2005))$. Like the Flat Tax, the $X$-tax would use the subtraction method and impose tax at a single rate on business cash flow, defined as sales minus the cost of materials, labor, and purchases of business assets. The $\mathrm{X}$-tax modifies the Flat Tax by employing multiple tax brackets (above the zero bracket) for labor earnings. For example, an X-tax could have a 15 percent bracket below some threshold and a 30 percent rate above it. ${ }^{14}$

Returning to our earlier example, imagine that the farmer grows barley and hops using lower-earning labor (subject to tax on wages in a lower tax bracket). The brewer uses a mix of lower-earn- ing labor and higher-earning labor to make beer, and the retailer uses a mix of lower-earning and higher-earning labor to sell kegs to consumers. Lines 5 through 8 of Example 2 (Table 2) show the nowfamiliar treatment of these transactions under a subtraction-method VAT and a credit-method VAT assessed at a rate of 30 percent. Lines 9 through 12 demonstrate how the same transactions would be taxed under a subtraction-method X-tax.

Example 2 shows that businesses remit less tax to the government under an X-tax than they do under a VAT (compare line 9 to line 8 ), because a portion of the value added is taxed at the individual level. The difference in total collections under the $X$-tax is due to the fact that the labor component of value associated with lower-earning workers is taxed at a reduced rate of 15 percent. Line 3 a shows

TABLE 2

EXAMPLE 2: SUBTRACTION-METHOD VAT, CREDIT-METHOD VAT, AND SUBTRACTION-METHOD X-TAX

\begin{tabular}{|c|c|c|c|c|}
\hline Economic Activity & Farmer & Brewer & Retailer & Total \\
\hline \multicolumn{5}{|l|}{ Basic transactions } \\
\hline 1. Sales & $\$ 30$ & $\$ 70$ & $\$ 100$ & \\
\hline 2. Purchases & $\$ 0$ & $\$ 30$ & $\$ 70$ & \\
\hline 3a. Lower-bracket labor & $\$ 20$ & $\$ 10$ & $\$ 20$ & \\
\hline 3b. Higher-bracket labor & $\$ 0$ & $\$ 10$ & $\$ 6$ & \\
\hline 4. Value added (sales - purchases) & $\$ 30$ & $\$ 40$ & $\$ 30$ & $\$ 100$ \\
\hline \multicolumn{5}{|l|}{ Subtraction-Method VAT } \\
\hline $\begin{array}{l}\text { 5. VAT liability } \\
(30 \% \text { of line } 4)\end{array}$ & $\$ 9$ & $\$ 12$ & $\$ 9$ & $\$ 30$ \\
\hline \multicolumn{5}{|l|}{ Credit-Method VAT } \\
\hline 6. Tax on sales ( $30 \%$ of line 1$)$ & $\$ 9$ & $\$ 21$ & $\$ 30$ & \\
\hline 7. Less: input tax on purchases & $\$ 0$ & $\$ 9$ & $\$ 21$ & \\
\hline 8. Net VAT liability & $\$ 9$ & $\$ 12$ & $\$ 9$ & $\$ 30$ \\
\hline \multicolumn{5}{|l|}{ Subtraction-Method X-tax } \\
\hline $\begin{array}{l}\text { 9. Tax paid at business level } \\
(0.3 \times(\text { line } 4-\text { line } 3 a-\text { line } 3 b))\end{array}$ & $\$ 3$ & $\$ 6$ & $\$ 1.20$ & $\$ 10.20$ \\
\hline $\begin{array}{l}\text { 10. Tax paid at individual level- } \\
\text { lower bracket }(15 \% \text { of line } 3 a)\end{array}$ & $\$ 3$ & $\$ 1.50$ & $\$ 3$ & $\$ 7.50$ \\
\hline $\begin{array}{l}\text { 11. Tax paid at individual level- } \\
\text { higher bracket ( } 30 \% \text { of line } 3 \mathrm{~b})\end{array}$ & $\$ 0$ & $\$ 3$ & $\$ 1.80$ & $\$ 4.80$ \\
\hline 12. Total subtraction-method $\mathrm{X}$-tax collections & $\$ 6$ & $\$ 10.50$ & $\$ 6$ & $\$ 22.50$ \\
\hline
\end{tabular}

14 The Tax Reform Panel's pure X-tax proposal, the "Progressive Consumption Tax," utilized three tax rates on labor compensation ranging from 15 percent to 35 percent, as well as a zero-bracket amount (Tax Reform Panel, 2005). Robert Hall explained to the Tax Reform Panel that he now advocates an X-tax rather than a Flat Tax because the "consumption gap" between more prosperous and less prosperous Americans has widened in the 25 years since he first proposed the Flat Tax (see Hall (2005)). 
that $\$ 50$ of the $\$ 100$ of value associated with the keg is generated by lower-earning labor. That $\$ 50$ of value is taxed at the business level under the VAT, producing $\$ 15$ of revenue for the government at a 30 percent rate. In contrast, the $\mathrm{X}$-tax taxes that value-added at a 15 percent rate, raising only $\$ 7.50$. This difference accounts for the $\$ 7.50$ reduction in collections under the X-tax as compared to the VAT. The 15 percent rate on the wages of lower-earning labor makes the $\mathrm{X}$-tax more progressive than its Flat Tax cousin.

\section{CREDIT-METHOD AND SUBTRACTION-METHOD CONSUMPTION TAXES IN THE REAL WORLD}

In this article, I argue that replacing the income tax with a consumption tax based on a credit-method VAT and other progressive offsets would likely result in a more administrable and economically efficient system than if a progressive consumption tax were implemented using the subtraction method.

David Weisbach (2003) elegantly demonstrates that purported substantive differences between the subtraction method and the credit method are not inherent to the two methods of calculation. Any differences, such as the ability to deduct the cost of inputs purchased from nontaxpayers or the flexibility to impose preferential tax rates on specific goods or services, are based on the amount of information that analysts assume will be collected in credit-method and subtraction-method systems, respectively. With the same information collection and parallel design decisions, the two methods can, in principle, be made to produce identical results on any relevant policy dimension. ${ }^{15}$

More practically, however, using the credit method makes it more likely that worldwide credit-method norms will be adopted, while using the subtraction method makes it more likely that the information that is collected will be similar to the sort of information that is collected under our present subtraction-method corporate income tax or the subtraction-method Japanese system. In any consumption tax, business-level deductions or credits are appropriate only for inputs on which consumption tax was paid by the seller. To the extent insufficient information is collected to enforce this rule, significant tax planning opportunities arise to enter into transactions where a deduction of an input cost by one party is not offset by an inclusion by the other. ${ }^{16}$

Some claim that a subtraction-method system is more likely to survive the political process than a credit-method system because it can be described as a gradual reform of the current system. At first glance, the only differences between a subtraction-method consumption tax and a corporate income tax are expensing and the loss of interest deductions. These are major changes, but in political circles these changes may seem minor relative to the perceived sea-change of repealing the corporate income tax and replacing it with a credit-method VAT assessed at the cash register.

Those who claim that a subtractionmethod system would be easier to pass politically than a credit method system because of its relative familiarity ${ }^{17}$ should recognize that maintaining that familiarity creates pressures to retain design

15 Sophisticated proponents of subtraction-method cash flow taxes generally support adoption of credit-invoice type rules in adopting the subtraction method (see, for example, Weisbach (2003) and Hufbauer and Greico (2005)).

16 See Weisbach (2000) for a discussion of these problems.

17 The Tax Reform Panel, for example, suggested that its X-tax "would be implemented using the subtraction method because it is closer to current law methods of accounting." (Tax Reform Panel, 2005, p. 163). 
features that resemble those contained in the present corporate income tax. These design features, in turn, form part of the basis for other analysts' claims regarding the superiority of the credit method over the subtraction method. ${ }^{18}$ One major concern is that a subtraction-method system would be vulnerable to a political compromise that allowed capital investments to be expensed without eliminating deductions for interest expense. ${ }^{19}$ Such a system would provide an economically distortive tax subsidy to new investment. The treatment of small businesses and the treatment of losses provide two further examples of how advocating a subtraction-method system because of its relative familiarity is likely to result in suboptimal design decisions.

\section{Small Business}

A small business exemption is included as part of most credit-method VATs. A credit-method VAT can exempt many small businesses from collecting the tax at relatively low cost, because the VAT is collected at every stage of production and many businesses buy many of their inputs from larger businesses. Exempted busi- nesses tend to account for a relatively small fraction of gross receipts and continue to pay VAT on their inputs, limiting revenue loss, while some businesses eligible for exemption voluntarily choose to collect VAT in order to pass input tax credits on to their customers. Thus, a VAT exemption, if implemented with a reasonably high threshold, is administratively appealing. ${ }^{20}$ It simplifies enforcement efforts by substantially decreasing the number of VAT returns the IRS would receive..$^{21}$ As the compliance costs associated with a VAT are low overall, but may be disproportionately high for many small businesses, a small business exemption also minimizes the impact that the administrative costs of the VAT may have on business.

A credit-method tax would likely be perceived as a tax on individual transactions, like a sales tax. The small business exemption would simply be a feature of the new tax system. However, Congress may be less prepared politically to exempt small-business owners from taxation in a subtraction-method system. It may be politically difficult to exempt from tax an "accounts-based" amount that would remain, in most people's eyes, akin to the profits of a small business. ${ }^{22}$

18 For example, McClure's (2005) suggestion that the subtraction method is more politically vulnerable to demands for exemptions is based on the premise that in a subtraction-method system deductions would be available for purchases from non-taxpayers, as they are in the present corporate income tax.

19 Pearlman (2005) provides an example of this concern. See also Tax Reform Panel (2005).

20 Preliminary estimates for 2003 suggest that only 1.8 percent of gross receipts in the United States are collected by businesses with less than $\$ 100,000$ in gross receipts. A gross receipts exemption threshold of approximately $\$ 100,000$ would entail relatively little revenue loss for the fisc according to a 1993 Governmental Accountability Office study (U.S. GAO, 1993). The GAO estimated that in 1993 a U.S. VAT collection threshold of $\$ 100,000$ would have reduced the number of businesses filing VAT returns in the United States from 24 million to about 9 million.

21 Providing a small business exemption does create the potential for firms to avoid VAT by organizing their activities in a series of small enterprises. Anti-abuse rules that aggregate related firms for purposes of applying the VAT threshold would, therefore, be necessary. Some commentators suggest that these rules can be quite burdensome (Bankman and Schler, 2005). However, the present income tax utilizes many rules that turn on direct, indirect, or constructive control of one enterprise by another. As a whole, the simplification and enforcement benefits of a VAT threshold for small business exemption seem to substantially outweigh the burden of enforcing a deconsolidation anti-abuse rule associated with the VAT threshold. Thus, to the extent that a small-business threshold would be incorporated into a credit-method system but not a subtraction-method system, the small business exemption factor weighs in favor of a credit-method consumption tax system.

22 This sentiment exists even in some countries with credit-method systems. Italy and Spain do not provide for small business exemptions in their VATs, although they do allow for presumptive taxation based on firm characteristics and substantially reduced reporting requirements (Ebrill, Keen, Bodin, and Summers, 2001). 


\section{Losses}

Similar perception problems may impact the treatment of losses in a subtraction-method system. All credit-method systems provide near-immediate full refunds for losses. ${ }^{23}$ Tax systems that do not provide full and immediate refunds for losses impose a higher effective tax rate on higher-risk and startup ventures than on other businesses. Fully refunding losses ensures that the tax system does not disproportionately discourage risky ventures. However, for cosmetic reasons of the same variety that affect the small business exception, business-level losses are unlikely to be fully refundable in a subtraction-method X-tax. The corporate income tax system allows losses to be carried back and carried forward, to claim refunds for prior years or reduce tax liability in future years. ${ }^{24}$ Thus, it is likely to be difficult to explain immediate full refunds for business losses in a tax that is marketed as a gradual reform. In fact, neither the Flat Tax nor the GIT proposed by the Tax Reform Panel included a provision for fully and immediately refundable losses. Instead, each of those proposals would have businesses carry losses forward with interest.

Small business and loss refunds are only two examples of areas where the consequences of marketing a consumption tax as a reform of the current system rather than as an entirely new tax system will affect the viability and effectiveness of the result. Gradual transition to a subtraction-method consumption tax from a corporate income tax would also be more complicated than the adoption of a credit-method VAT. The more dramatic perceived differences between a credit-method system and the corporate income tax make a credit-method system easier to adopt "cold turkey." 25

\section{WORLD TRADE ORGANIZATION RULES AND THE BORDER TAX ADJUSTMENT ISSUE}

\section{What Is a Border Tax Adjustment?}

Consumption taxes can be imposed on either a "destination basis" or an "origin basis." 26 A "destination-basis" tax excludes exports from the tax base and includes imports in the tax base. Thus, domestic consumption is taxed regardless of where the goods being consumed are produced. ${ }^{27}$ An origin-basis tax includes exports in the tax base and excludes imports from the tax base. The tax base in an origin-basis system is equal to the value of goods and services produced in the taxing jurisdiction, regardless of where those goods and services are consumed. Thus, an origin-basis tax is imposed on the entire value of goods and services produced domestically (whether sold at home or abroad), but taxes only the U.S. markup (value added in the United

${ }^{23}$ If firms have losses, the subtraction-method X-tax and the credit-method X-tax often will not produce the same results, nor would either tax produce the same result as a stand-alone credit-method VAT. Space does not permit me to fully address these issues here.

24 Net operating losses can generally be carried back for two years or carried forward for 20 years. Many limitations and special rules apply, including rules limiting or disallowing the carryover of net operating losses when stock ownership in a corporation shifts in specified ways (See $\S 172$ and $\S \S 381$ through 384 of the Internal Revenue Code).

25 Demands for transition relief may also be more intense in a subtraction-method X-tax than they would be under a credit-method system (Graetz, 1997). As a political matter, it is likely to be easier to deny relief if the perception is that the corporate income tax has been eliminated and replaced with an entirely new tax system. For a discussion of the political dynamics of consumption tax reform, see Shaviro (2006).

26 See Grubert and Newlon (1995) for an excellent discussion of international implications of consumption taxes.

27 Symmetrically, foreign consumption is not taxed, regardless of whether the goods are produced domestically. 
States) to the value of imported goods and services. ${ }^{28}$

Imposing the VAT, the Flat Tax, or the $\mathrm{X}$-tax on a destination basis (taxing imports and excluding exports from tax) requires a border adjustment. To eliminate the tax paid on an exported good by businesses at earlier stages in the production and distribution process, an exporter receives a refund for tax paid on its inputs under a credit-method system, even though no tax is assessed on export sales (because the good or service is not being consumed in the United States). Similarly, in a subtraction-method system the taxpayer is allowed to deduct inputs associated with export sales even though it does not include export sales in taxable cash flow for purposes of determining its tax liability. Sales for which a business can claim input credits or deductions even though tax is not assessed on related sales are "zero-rated" sales. The tax refund associated with zero-rated export sales is called a "border adjustment."
Example 3 (Table 3) illustrates the mechanics of a border adjustment using a VAT imposed via either the subtraction method or the credit method. Example 3 is identical to Example 1, except that the keg produced by the brewer is purchased by an exporter and sold abroad. As a result, a border adjustment is due with respect to the VAT paid on the beer at earlier stages of production. As line 5 and line 8 show in the last column, once a border adjustment is provided to the exporter, net VAT collected by the government is zero.

\section{Border Adjustability of a Subtraction- Method X-tax}

In principle, a subtraction-method $\mathrm{X}$-tax can be border-adjusted in the same way as a subtraction-method VAT. Inputs associated with export sales can be deducted even though export sales revenue is not included.

However, under current WTO rules as originally developed under The General

TABLE 3

EXAMPLE 3: BORDER ADJUSTED VATS

\begin{tabular}{lcccc}
\hline Economic Activity & Farmer & Brewer & Beer Exporter & Total \\
\hline Basic transactions & $\$ 30$ & & \\
1. Sales & $\$ 0$ & $\$ 70$ & $\$ 100$ (zero-rated) \\
2. Purchases & $\$ 20$ & $\$ 10$ & $\$ 70$ & $\$ 20$ \\
3a. Lower-bracket labor & $\$ 0$ & $\$ 10$ & $\$ 6$ & $-\$ 70$ \\
3b. Higher-bracket labor & $\$ 30$ & $\$ 40$ & & $\$ 100$ \\
4. Value added (sales - purchases) & & & $-\$ 21^{*}$ & \\
Subtraction-Method VAT & $\$ 9$ & $\$ 12$ & & \\
5. Subtraction-method VAT & & & $\$ 0$ \\
$\quad$ (30\% of line 4) & & & $\$ 0$ (zero-rated) \\
Credit-Method VAT & $\$ 9$ & $\$ 21$ & $\$ 21^{*}$ & $-\$ 21$ \\
6. Tax on sales (30\% of line 1) & $\$ 0$ & $\$ 12$ & & \\
7. Less: input tax on purchases & $\$ 9$ & & & \\
8. Net VAT liability & & & \\
\hline
\end{tabular}

*Border adjustment.

\footnotetext{
28 Not surprisingly, many U.S. companies oppose this treatment of exports and imports. Because the tax does not tax the full value of imported goods and services that are consumed domestically, it appears to favor imports. Economic theory suggests the benefit to imports from origin-basis treatment will be offset by currency exchange rates or other changes in the price level. See Viard (2004) for a discussion of the economics of border adjustments. The possibility that adjustments would occur other than through exchange rates and over an extended transition period was a source of concern for the Tax Reform Panel (Tax Reform Panel, 2005, p. 173).
} 
Agreements on Tariffs and Trade (GATT), a border tax adjustment must meet two criteria to avoid being deemed a prohibited trade subsidy. First, the tax must not be a "direct" tax. The WTO's Agreement on Subsidies and Countervailing Measures (ASCM) prohibits member states from taxing imports and rebating tax paid on exports for "direct" taxes. In contrast, WTO rules allow countries to borderadjust "indirect taxes." A subtractionmethod X-tax would almost certainly be treated as a direct tax under GATT rules. Second, the rebate on the export of a good or service must not exceed the amount levied on the same good or service when sold for domestic consumption. Measuring the amount levied on the same good or service when sold for domestic consumption under an $\mathrm{X}$-tax is likely to be complex and controversial.

\section{"Direct" vs. "Indirect" Tax}

The ASCM treats exempting or remitting "direct" taxes on exports as a prohibited export subsidy, thereby prohibiting border adjustments of such taxes. ${ }^{29}$ The ASCM defines direct taxes as "taxes on wages, profits ... and all other forms of income." (ASCM, 1994, Annex VII[58]). In contrast, indirect taxes are defined as "sales, excise, turnover, value added . . . and all taxes other than direct taxes and import charges." (ASCM, 1994, Annex VII[58]).

Some observers claim that the GATT's distinction between direct and indirect taxes arose at the urging of the United States during negotiations leading to the initial adoption of the GATT in 1947. According to this account, U.S. negotiators sought a border adjustment rule that paralleled U.S. sales and corporate income tax rules for interstate transactions (Gibbons, 2002). States do not assess sales tax on sales made by companies inside their borders to customers outside the state, but income from these sales is taxable under state corporate income taxes. ${ }^{30}$

Others claim that the distinction in the ASCM between direct and indirect taxes arose due to a (faulty) assumption that the burden of indirect taxes was shifted onto the consumer, whereas direct taxes were borne by the legal payor. ${ }^{31}$ Since indirect taxes were thought to be imposed on the ultimate consumer rather than on the producer, reimbursing such a tax was not viewed as an export subsidy; any consumption tax revenues would appropriately be collected by the government of the nation in which the consumer resides. In contrast, the corporate income tax was thought to reduce corporate profits, so that rebating that tax would transfer money from the nation of consumption

29 An illustrative list of export subsidies in Annex I of the ASCM includes “... special deductions directly related to exports or export performance, over and above those granted in respect to production for domestic consumption, in the calculation of the base on which direct taxes are charged." (ASCM, 1994, Annex I(f)).

30 The GATT's distinction between direct and indirect taxes conforms to the definition of those terms used in U.S. domestic jurisprudence, further suggesting that the United States may have proposed the direct/indirect tax distinction in the GATT. In U.S. domestic law, an indirect tax is understood to be a tax that is imposed on goods, rather than income or wealth. (See Zenith Radio Corp v. United States (1978), United States v. State of West Virginia (2003)). This understanding in fact predates the Founding. ("[T]axes may be subdivided into those of the direct kind and those of the indirect kind... [A]s to the latter, by which must be understood duties and excises on articles of consumption, one is at a loss to conceive what can be the nature of the difficulties comprehended" (The Federalist No. 36, Alexander Hamilton, available in Hamilton, Madison, Jay, 1961, p. 219).)

31 The modern understanding is that the incidence of a unit tax on consumption depends on the elasticities of supply and demand. (See, e.g., Rosen (2004)). Research suggests that consumption taxes are borne primarily by consumers, wage taxes imposed at the individual level are borne by wage earners, wage taxes imposed at the business level (such as the employer portion of social security and Medicare taxes) are borne either by workers or by consumers generally, and corporate income taxes are borne in part by labor and in part by capital (Atkinson, 2004); the incidence of taxes on capital income is controversial within the economic profession (Fuchs, Krueger, and Poterba, 1998). 
to the nation of production (Graetz, 1997). The 1970 GATT Working Party on Border Adjustments stated that "direct taxeseven assuming that they were passed on into prices-were borne by entrepreneurs' profits" (GATT, 1970). In contrast, the 1970 Report suggested that the VAT was directly levied on products and therefore was borne by the consumer. ${ }^{32}$

Unlike a credit-method VAT, a subtraction-method X-tax does not appear to be a tax imposed on sales to consumers. Rather, because it is formally accounts-based and utilizes deductions rather than credits, the subtraction-method $X$-tax resembles a tax on corporate income or profits. Further, the regime includes a tax on wages. As a result, a subtraction-method X-tax would likely be treated as a direct tax if challenged at the WTO (Summers, 1996).

Recognizing this problem, the Tax Reform Panel chose not to include the revenues that border adjustments would have generated over the budget window in determining whether its GIT proposal was revenue neutral. ${ }^{33}$ With the $\$ 775$ billion raised by border adjustments under the estimates provided to the Panel by the Treasury Department, the Panel could have proposed tax rates that would have been lower across the board by approximately five percent. ${ }^{34}$ The choice not to use the revenues from border adjustments thus suggests that the Panel believed that a subtraction-method X-tax most probably is not border adjustable under current WTO rules. ${ }^{35}$

\section{Excessive Exemption or Remission of Tax}

In addition to prohibiting border adjustments of direct taxes, the ASCM requires that border adjustments for indirect taxes not exceed the tax levied on similar products sold in the domestic market (See ASCM (1994, Annex I(g))). ${ }^{36}$ Example 4 (Table 4) compares the treatment of an exporter under a VAT and a subtraction-method $\mathrm{X}$-tax. If the beer exporter is permitted to deduct both the value of purchases and labor associated with export sales without taking those sales into account in calculating taxable cash flow, the exporter will be owed a refund of $\$ 28.80$ for each keg sold under the X-tax (as shown in line 9). This compares with a rebate of only $\$ 21$ for the exporter under a VAT (as shown in line

32 The Report concluded that the value-added tax was border-adjustable because "it was agreed [that] regardless of its technical construction (fractioned collection), [the VAT] was equivalent in this respect to a tax levied directly-a retail or sales tax" (GATT, 1970).

33 Border adjustments raise revenue when a country is a net importer because more money is collected on imports than must be refunded with respect to exports. The U.S. is a large net importer, and will be so for the foreseeable future. Economists, however, point out that trade deficits cannot last forever-eventually the U.S. must pay for its consumption of foreign goods or services with U.S. goods or services. Another implication of this basic identity of economics is that border adjustments will not raise revenue in net present value terms over an infinite time horizon (if one assumes VAT rates remain constant.) In fact, on a net present value basis over an infinite horizon the United States would actually lose revenue by imposing a border adjustment. A border adjustment is equivalent to providing a deduction for net foreign investment and levying a tax on net foreign-source income. Because the United States is a net debtor to the rest of the world, this adjustment should reduce U.S. government revenue from a VAT (Auerbach, 1997).

34 The Tax Reform Panel report noted that had the Panel not needed to pay for an AMT "patch," it would have had to raise $\$ 866$ billion less in revenue to be "revenue neutral" and, therefore, could have reduced rates across the board by 5.6 percent (Tax Reform Panel, 2005, p. 189).

35 The Tax Reform Panel report states that "[g]iven the uncertainty over whether border adjustments would be allowable under current trade rules, and the possibility of challenge from our trading partners, the Panel chose not to include any revenue that would be raised through border adjustments in making the Growth and Investment Tax Plan revenue neutral." (Tax Reform Panel, 2005, p. 172).

36 GATT/WTO prohibits "exemption or remission in respect of the production and distribution of exported products of indirect taxes in excess of those levied in respect of the production and distribution of like products when sold for domestic consumption." 
TABLE 4

EXAMPLE 4: SUBTRACTION-METHOD VAT, CREDIT-METHOD VAT, AND SUBTRACTION-METHOD X-TAX WITH BORDER ADJUSTMENTS

\begin{tabular}{|c|c|c|c|c|}
\hline Economic Activity & Farmer & Brewer & Beer Exporter & Total \\
\hline \multicolumn{5}{|l|}{ Basic transactions } \\
\hline 1. Sales & $\$ 30$ & $\$ 70$ & \$ 100 (zero-rated) & \\
\hline 2. Purchases & $\$ 0$ & $\$ 30$ & $\$ 70$ & \\
\hline 3a. Lower-bracket labor & $\$ 20$ & $\$ 10$ & $\$ 20$ & \\
\hline 3b. Higher-bracket labor & $\$ 0$ & $\$ 10$ & $\$ 6$ & \\
\hline 4. Value added (sales - purchases) & $\$ 30$ & $\$ 40$ & $-\$ 70$ & $\$ 100$ \\
\hline \multicolumn{5}{|l|}{ Subtraction-Method VAT } \\
\hline $\begin{array}{l}\text { 5. Subtraction-method VAT } \\
(30 \% \text { of line } 4)\end{array}$ & $\$ 9$ & $\$ 12$ & $-\$ 21^{*}$ & $\$ 0$ \\
\hline \multicolumn{5}{|l|}{ Credit-Method VAT } \\
\hline 6. Tax on sales ( $30 \%$ of line 1$)$ & $\$ 9$ & $\$ 21$ & $\$ 0$ (zero-rated) & $\$ 0$ \\
\hline 7. Less: input tax on purchases & $\$ 0$ & $\$ 9$ & $\$ 21$ & \\
\hline 8. Net VAT liability & $\$ 9$ & $\$ 12$ & $-\$ 21^{*}$ & \\
\hline \multicolumn{5}{|l|}{ Subtraction-Method X-tax } \\
\hline $\begin{array}{l}\text { 9. Tax paid at business level } \\
(0.3 \times(\text { line } 4-\text { line } 3 a-\text { line } 3 b))\end{array}$ & $\$ 3$ & $\$ 6$ & $-\$ 28.80 *$ & $-\$ 19.80$ \\
\hline $\begin{array}{l}\text { 10. Tax paid at individual level- } \\
\text { lower bracket ( } 15 \% \text { of line } 3 a)\end{array}$ & $\$ 3$ & $\$ 1.50$ & $\$ 3$ & $\$ 7.50$ \\
\hline $\begin{array}{l}\text { 11. Tax paid at individual level- } \\
\text { higher bracket }(30 \% \text { of line } 3 \mathrm{~b})\end{array}$ & $\$ 0$ & $\$ 3$ & $\$ 1.80$ & $\$ 4.80$ \\
\hline 12. Total subtraction-method X-tax & $\$ 6$ & $\$ 10.50$ & $-\$ 24$ & $-\$ 7.50$ \\
\hline
\end{tabular}

*Border adjustment.

8), despite the fact that the tax rate is the same. As a result, some WTO members may be inclined to challenge whether the $\$ 28.80$ border adjustment resulting is too high under WTO rules. They would argue that the rebate is in excess of the amount levied on goods when sold for domestic consumption because it is paid at the tax rate applicable to business cash flow, while wages are deducted and taxed progressively. ${ }^{37}$ On the other hand, determining the tax actually assessed on the labor component of value added to each individual exported product in order to provide precise border adjustments may be highly problematic. Thus, a subtraction-method X-tax may not be able to meet the WTO's standard prohibiting "excessive" border adjustments.

\section{ADMINISTRATION AND ENFORCEMENT PROBLEMS IN AN ORIGIN-BASIS SUBTRACTION- METHOD X-TAX}

Without border adjustments, a subtraction-method X-tax would be susceptible to unintended revenue-reducing cross-border transactions and face related problems of administration and enforcement. ${ }^{38}$ Taxpaying businesses would be able to deduct purchases from foreign businesses that do not pay U.S. tax. Thus, taxpayers could claim deductions that would not be offset by corresponding inclusions by other taxpayers. For this and related enforcement reasons, the Tax Reform Panel rightly expressed a preference for a border-adjustable con-

37 Permitting border adjustments of an X-tax at the rate applicable to business cash flow could be defensible. Consider what would happen in a VAT if all workers were treated as their own business and assessed VAT on the labor they supplied their employers. If each worker was her own VAT-assessing business, a credit-method VAT applied to Example 4 would produce a border adjustment of $\$ 28.80$, just like the subtraction-method X-tax.

38 In Weisbach's terminology, the system would be "open" (what McClure calls "naïve") with respect to cross-border transactions (See e.g., Weisbach (2000), Weisbach (2003), McLure (1998)). 
sumption tax (Tax Reform Panel, 2005, p. 167).

The most widely discussed problem with an origin-basis consumption tax is its susceptibility to transfer pricing problems. ${ }^{39}$ Transfer prices are the amount charged by related entities in sales and transfers to one another. These entities have incentives to set prices in their transactions with one another to minimize tax, rather than on an "arm's length" basis. Transfer pricing is also a major problem in enforcing the present international tax regime. Nevertheless, there are some reasons to fear that transfer pricing problems might be even more severe under an origin-basis $\mathrm{X}$-tax than under current law. ${ }^{40}$ In contrast, border adjustments limit the tax base to domestic consumption. The price established in cross-border transactions is irrelevant to the amount of revenue collected, because purchases from abroad do not provide a deduction and producing goods or services in the United States that are consumed abroad does not create taxable cash flow (See e.g., Tax Reform Panel (2005, p. 169)). ${ }^{41}$ Thus, transfer pricing ceases to be an issue.

Related serious tax avoidance problems may also arise in an origin-basis system. Bankman and Schler (2005) and Weisbach
(2000) detail some of the potential problems in the literature. Simple transactions can be used to defer tax indefinitely, such as using any gains on domestic sales to buy foreign real assets (such as foreign real estate) from a related foreign seller (Bradford, 2001). Slightly more complicated intercompany transactions may be used to manufacture deductions with little economic risk. For example, Weisbach suggests that a U.S. business could set up a shell corporation in the Cayman Islands (Weisbach, 2000). The shell borrows money from the U.S. parent and promises to repay a contingent amount in the future. The Cayman shell then uses the borrowed money to purchase an asset from the U.S. business. The business agrees to repurchase the asset around the same time the loan is due for a contingent amount that is similar to the amount that is due on the loan. The cash flows on the transaction wash out, so the U.S. business will neither gain nor lose money. However, the contingency clauses can be structured so as to virtually guarantee the purchase price and the amount due on the loan will go up substantially. The tax result is a small inclusion from the sale of the asset initially and a much larger deduction when the asset is repurchased. ${ }^{42}$

39 Bradford focused heavily on the transfer pricing concern in the course of his writings regarding the international aspects of the X-tax (See, e.g., Bradford (2004)).

40 At least before section 103 of the Tax Increase Prevention and Reconciliation Act of 2005 (2005 Act) became law, subpart $\mathrm{F}$ base company rules backstopped transfer pricing enforcement when U.S. multinationals attempted to shift sales or services income to low-tax jurisdictions. Under the United States' current regime for taxing international income, taxation of foreign-source income of a foreign subsidiary of a U.S. company is generally deferred until such time as that income is repatriated to the United States. In contrast, in an origin-basis X-tax, obtaining foreign-source treatment for cash flow permanently exempts that cash flow from U.S. taxation. Thus, incentives to manipulate rules deeming in which country a good or service is "produced" and transfer prices to minimize the value of "U.S.-produced" sales may be stronger under the X-tax than current incentives to manipulate transfer prices and sourcing rules to limit current year U.S. income tax liability. (See, generally, Graetz and Oosterhuis (2001)).

41 A destination-basis system does, however, face what Bradford referred to as the "tourism problem," whereby individuals can reduce their taxes by consuming in low-tax jurisdictions (Bradford, 2004).

42 This tax avoidance transaction could also be accomplished in transactions with domestic taxpayers that are not registered business-level taxpayers were it not for the invoice requirement for deductions. The potential abuse with individuals as counterparties would exist under either an origin-basis system or a destination-basis system. This article assumes that an invoice requirement would be imposed domestically under either an origin-basis or a destination-basis subtraction-method X-tax, thereby limiting the potential issue to cross-border transactions. Even without an invoice requirement, as a practical matter the likeliest counterparties for large-scale abuses of this sort would generally seem to be foreign businesses rather than domestic individuals. 
A destination-basis system avoids these problems because a U.S. business does not have a deduction when it buys an asset from the foreign seller.

Taxpayers may also find it easier to manipulate the distinction between real and financial transactions to their advantage in an origin-basis system than in a destination-basis system. ${ }^{43}$ Bankman and Schler (2005) provide the example of a taxpayer entering into offsetting long and short forward contracts for delivery of goods. The taxpayer settles the favorable side of the straddle for cash, resulting in nontaxable gain from a financial transaction, and takes delivery on the loss transaction, resulting in a deductible loss (Bankman and Schler, 2005; Weisbach, 2000). In a destination-basis system, the loss would only be deductible if it was offset by taxable gain to the counterparty. In an origin-basis system, however, a transaction involving a foreign counterparty that does not pay U.S. tax would still result in a deduction for the U.S. taxpayer, so that there would be an overall loss to the U.S. fisc.

Finally, an origin-basis system faces transition problems that a destinationbasis system would avoid. In an origin-basis system, firms would have a strong incentive to sell assets with basis to foreign non-taxpaying counterparties immediately prior to transition and to repurchase the assets after the effective date of the new tax system. ${ }^{44}$ Doing so could provide "self-help" transition relief. The taxpayer's basis in the asset would limit the taxpayer's tax liability on the sale in the year prior to implementation of the X-tax. Repurchase of the assets after transition would provide a deduction after the origin-basis X-tax was implemented, thereby preserving the value of pre-transition basis in the assets. ${ }^{45}$

Economic substance and sham transaction-type doctrines similar to those that exist under current law could be used to address simple versions of the transactions discussed above. However, international tax planners would likely find ways to add "substance" by encasing tax-reduction strategies in broader transactions. Destination-basis systems avoid this problem by making purchases from foreign non-taxpayers non-deductible.

\section{WHAT ABOUT A "CREDIT-METHOD X-TAX"?}

International trade law creates a catch-22 for a subtraction-method X-tax (Weisbach, 2003). A destination-basis subtraction-method X-tax violates GATT/ WTO requirements for border adjustability, while an origin-basis system has grave administrative flaws. But a subtraction-method X-tax is only one of

43 The distinction between financial institutions and other institutions can also be manipulated in standard credit-method VATs to reduce VAT liability among related parties. (See, e.g., Halifax PLC and others v. Commissioners of Customs and Excise (2001 and 2002), Halifax and Others v. Customs and Excise Commissioners (2006), Nias and Manchia (2006)).

44 A destination-basis system would have a similar incentive with respect to pre-transition sales of assets to U.S. individuals, but relatively few individuals would have the wherewithal to purchase large assets and anti-abuse rules would be easier to police.

45 The Tax Reform Panel proposed a four-year phase-in period to move their X-tax structure from an origin basis to a destination basis. They recommended that importers be able to deduct 90 percent, 60 percent, and 30 percent of the cost of their imports in years one through three of the GIT, and similarly provided that exporters would pay tax on 90,60, and 30 percent of the value of export sales in years one through three (Tax Reform Panel, 2005, p.173-4). The Panel justified this approach by arguing that if exchange rates did not adjust as rapidly as economic theory would suggest, border adjustments would place an undue burden on importers (Tax Reform Panel, 2005, p. 173-4). However, the border-adjustment phase-in allows taxpayers to obtain self-help transition relief by parking assets with foreign taxpayers immediately prior to adoption of the GIT, repurchasing that asset and receiving a deduction equivalent to 90 percent of the value of the asset in year one of the GIT. 
many options for making consumption taxes progressive. The Tax Reform Panel noted that its Growth and Investment Tax proposal is "equivalent to a credit-method VAT at a 30 percent rate, coupled with a progressive system of wage subsidies and a separate single-rate tax on capital income" (Tax Report Panel, 2005, p. 171). ${ }^{46}$

Comparing the advantages and disadvantages of a subtraction-method $X$-tax with a credit-method VAT paired with wage subsidies therefore seems appropriate. However, paying progressive wage subsidies to individuals encounters political resistance in the United States. ${ }^{47}$ On the other hand, both conservatives and liberals have proposed supports provided at the business level to encourage employment. ${ }^{48}$ Given bipartisan interest in hiring incentives at the business level, political constraints on wage subsidies paid to individuals, and the administrative advantages associated with a VAT, it makes sense to ask whether a progressive consumption tax that is economically similar to the X-tax could be developed through a system that couples a VAT with support payments at the business level- what this article calls a "Credit-method X-tax."

\section{Features of a "Credit-Method X-tax"}

A credit-method X-tax would combine three components: a credit-method VAT, employment support payments at the business level, and a wage tax. Together, the three components form an integrated system. ${ }^{49}$ The system could be designed to achieve the same distributional and revenue goals as an $\mathrm{X}$-tax.

\section{Credit-Method VAT}

Businesses would collect tax on all of their receipts except export sales. As in any credit-method VAT, businesses would reduce the amount of tax they were required to remit to the government by a credit for VAT paid on business expenses. Tax paid would be subtracted from tentative tax liability to determine the amount the business remits to the government. ${ }^{50}$

\section{Business-Level Support Payments}

Businesses would not pay VAT when purchasing labor under the credit-method $X$-tax, because labor is not supplied by

46 The tax on capital income was the income tax component of the GIT's income tax/consumption tax hybrid structure.

47 Even the Earned Income Tax Credit (EITC), a tax program that functions as a wage subsidy and is the nation's most important mean-tested entitlement program, generates substantial political controversy (see Ventry (2000)). In 1993, the budget bill that included the landmark expansion of the EITC did not receive a single Republican vote in the Senate (U.S. Congress, 1993). See also, for example, the remarks of Rep. Price (D-NC) in the floor debate on the 1993 bill, noting that "[i]n 1993, our Republican colleagues stand united against the earned income tax credit" (Price, 1993).

48 Calls for making the research and development tax credit "permanent," (part of President Bush's competitiveness agenda) are based on the claim that it will provide incentives for U.S. employers to create additional well-paying research and support positions in the United States (R\&D Credit Coalition, 2003). For example, Representative Cardin (D-MD), a member of the House Ways \& Means Committee, introduced legislation co-sponsored with Representative Johnson (R-CT) to make the R\&D credit permanent arguing that "R\&D is the engine that drives economic growth and helps create new, high-level jobs" (Cardin, 2005). Presidential candidate John Kerry prominently featured a Jobs Credit paid to businesses for hiring new employees in manufacturing and other sectors affected by outsourcing as part of his economic policy platform (Kerry and Edwards, 2004).

49 Hall and Rabushka (1995) have pointed out that the Flat Tax is one tax despite the fact that it has multiple components. The same is true of a credit-method X-tax.

50 The credit-method VAT would be collected by all businesses except for those qualifying small businesses choosing exemption. See notes 19-21, supra and accompanying text for further discussion of small business exemption under a VAT. Businesses choosing exemption would not receive the business-level support payments described herein. 
another VAT-registered business. There would be no VAT input credit with respect to wages and compensation paid.

However, businesses would receive a spending-side support payment based on the amount of wages and compensation paid to workers resident in the United States. ${ }^{51}$ The support payment would equal the business tax rate times the total wages a business paid to qualifying workers. This "American Jobs Credit" (AJC) would be administered separately from the VAT. It would be available to all registered businesses in all industries, regardless of whether the business was a domestic or foreign entity. ${ }^{52}$ All U.S. citizens and residents would be treated as qualifying workers.

\section{Wage Tax}

A tax on labor compensation at the individual level would complete the creditmethod X-tax system. That tax would be collected from workers using the wage withholding system as under current law. As a result, as in a subtraction-method $\mathrm{X}$-tax, the portion of value-added represented by wages would be taxed at the individual level.

\section{Equivalence}

Example 5 (Table 5) illustrates that the credit-method $X$-tax raises the same amount of revenue as a subtractionmethod X-tax, from the same parties, in the simple case in which products are not exported and companies have positive cash flow. ${ }^{53}$

The credit-method X-tax imposes a standard VAT. Thus (given the $30 \%$ tax rate), businesses face a total $\$ 30$ tax liability on the sale of a $\$ 100$ of product to final consumers (line 14, last column). In addition, employees pay a wage tax assessed at the same rate as under a subtraction-method X-tax. As with the subtraction-method X-tax, workers pay $\$ 12.30$ of tax on wages associated with $\$ 100$ of sales (line $15 a$, last column + line $15 \mathrm{~b}$, last column). In total, the government assesses tax liability of $\$ 42.30$ (line 16, last column).

Businesses then receive a support payment for employing workers subject to the wage tax. Businesses may net these support payments against tax liability. As a result of these support payments, which are shown in line 17, net revenues received by the government under the credit-method X-tax total $\$ 22.50$, just as they do under the subtraction-method $\mathrm{X}$-tax. Furthermore, each business (and each group of wage earners) makes the same net payment to the government as they would under the subtraction-method X-tax.

\section{WTO COMPLIANCE AND THE CREDIT-METHOD X-TAX}

The deduction for wages in the subtraction-method X-tax and the business support payments in the credit-method $X$-tax have the same effect-they both result in a consumption tax that taxes the value added by labor progressively. The purely formal structural differences between the two taxes do, however, produce a different result under the legalistic test applied by the GATT to determine border adjustabil-

${ }^{51}$ Qualifying persons could be either U.S. or foreign nationals. The requirement would be that they pay tax to the United States on their earned income.

52 Business registration requirements would be roughly similar to registration requirements under a credit-method VAT.

53 No assertion is intended as to whether the economic incidence of the subtraction-method X-tax and the credit-method X-tax would be perfectly identical. That question may warrant further study. 
ity. The credit-method X-tax should be WTO-compliant. ${ }^{54}$

\section{Credit-Method VAT}

WTO agreements specifically list the value-added tax as an "indirect" and, therefore, border-adjustable tax (ASCM, 1994, Annex I(g)). ${ }^{55}$ The credit-method VAT component of the credit-method $X$-tax would, therefore, be border adjustable.

\section{Acceptability of Business-Level Support Payments}

The business-level support payments included in the credit-method X-tax also would not raise WTO compliance questions. WTO rules permit programs outside of a country's tax system that encourage businesses to hire workers.

The ASCM permits subsidies that are not contingent on export performance or on using domestic rather than imported inputs, and that are not "specific" (ASCM, 1994, art. 8). If legislation "explicitly limits access to a subsidy to certain enterprises," a subsidy will be deemed "specific" (ASCM, 1994, art. 2.1(a)). If a government establishes "objective criteria or conditions" that govern both eligibility for and the amount of a subsidy, the subsidy is deemed to be non-specific (ASCM, 1994, art. 2.1(b)). WTO agreements provide that criteria or conditions are objective when they are spelled out in law, capable of verification, "neutral," do not favor certain enterprises over others, ${ }^{56}$ are economic in nature and "horizontal" in application (e.g., number of employees or size of enterprise) (ASCM, 1994, art. 2.1(b)).

Applying these criteria, the AJC would be permissible. The AJC is not contingent on export performance or the use of domestic over imported goods. Eligibility for the credit would be automatic and available to all U.S.-owned and foreign-owned businesses on exactly the same basis regardless of the type of business or industry. Employment support payments would not be limited to certain enterprises, and would be available to businesses regardless of whether workers are U.S. or foreign persons, so long as the worker pays U.S. individual-level tax. Those criteria do not favor some enterprises over others. Thus, the AJC meets the requirements for a permissible subsidy under the ACSM.

WTO agreements in fact explicitly sanction programs like the AJC. In the Tokyo Round of Agreements with respect to the GATT, signatories agreed that subsidies (other than export subsidies) intended "generally to sustain employment" were permitted as they were "important

54 Morrison (2006) suggested that an arrangement briefly described by Goldberg (2000) might also solve the WTO/GATT conundrum inherent in a traditional subtraction-method X-tax. That arrangement would treat all workers as if they were a business for VAT purposes. Wages would then be subject to VAT. For administrative purposes employers would withhold tax on wages at a single rate, and employees would credit that withholding against their progressive consumption liability. If the amount of VAT due on their wages was less than what had been withheld, an employee would claim a refund on a VAT return. Effectively, wage subsidy payments at the individual level would be styled as VAT refunds (Goldberg, 2000). The Goldberg/Morrison alternative, while intriguing, is susceptible to a few criticisms that do not apply to the credit-method X-tax. First, if workers were treated as VAT-paying businesses, it is not clear how a progressive rate schedule would apply to cash flow from wages but not taxable cash flow from sales. Second, VAT payroll withholding might be viewed as a "direct" wage tax that cannot be border adjusted under the WTO, rather than a VAT that can be border adjusted. Third, in such a system, all personal services provided abroad by U.S. persons would be border-adjustable exports.

55 The 1970 GATT Working Party Report on Border Tax Adjustments also concluded that indirect taxes were limited to taxes "directly levied on products." (GATT, 1970, para. 14).

56 Additionally, use or predominant use of a subsidy program by a limited number of enterprises, or by enterprises limited to a designated geographical region, and the manner in which any discretion is exercised by the granting authority may also make a subsidy specific (ASCM, 1994, art. 2.1(c)). 
TABLE 5

EXAMPLE 5: SUBTRACTION-METHOD VAT, CREDIT-METHOD VAT, SUBTRACTION-METHOD X-TAX, AND CREDIT-METHOD X-TAX

\begin{tabular}{|c|c|c|c|c|}
\hline Economic Activity & Farmer & Brewer & Retailer & Total \\
\hline \multicolumn{5}{|l|}{ Basic transactions } \\
\hline 1. Sales & $\$ 30$ & $\$ 70$ & $\$ 100$ & \\
\hline 2. Purchases & $\$ 0$ & $\$ 30$ & $\$ 70$ & \\
\hline 3a. Lower-bracket labor & $\$ 20$ & $\$ 10$ & $\$ 20$ & \\
\hline 3b. Higher-bracket labor & $\$ 0$ & $\$ 10$ & $\$ 6$ & \\
\hline 4. Value added (sales - purchases) & $\$ 30$ & $\$ 40$ & $\$ 30$ & $\$ 100$ \\
\hline \multicolumn{5}{|l|}{ Subtraction-Method VAT } \\
\hline $\begin{array}{l}\text { 5. VAT liability } \\
(30 \% \text { of line } 4)\end{array}$ & $\$ 9$ & $\$ 12$ & $\$ 9$ & $\$ 30$ \\
\hline \multicolumn{5}{|l|}{ Credit-Method VAT } \\
\hline 6. Tax on sales ( $30 \%$ of line 1$)$ & $\$ 9$ & $\$ 21$ & $\$ 30$ & \\
\hline 7. Less: input tax on purchases & $\$ 0$ & $\$ 9$ & $\$ 21$ & \\
\hline 8. Net VAT liability & $\$ 9$ & $\$ 12$ & $\$ 9$ & $\$ 30$ \\
\hline \multicolumn{5}{|l|}{ Subtraction-Method X-tax } \\
\hline $\begin{array}{l}\text { 9. Tax paid at business level } \\
(0.3 \times(\text { line } 4-\text { line } 3 a-\text { line } 3 b))\end{array}$ & $\$ 3$ & $\$ 6$ & $\$ 1.20$ & $\$ 10.20$ \\
\hline $\begin{array}{l}\text { 10. Tax paid at individual level- } \\
\text { lower bracket }(15 \% \text { of line } 3 a)\end{array}$ & $\$ 3$ & $\$ 1.50$ & $\$ 3$ & $\$ 7.50$ \\
\hline $\begin{array}{l}\text { 11. Tax paid at individual level- } \\
\text { higher bracket ( } 30 \% \text { of line } 3 \mathrm{~b})\end{array}$ & $\$ 0$ & $\$ 3$ & $\$ 1.80$ & $\$ 4.80$ \\
\hline $\begin{array}{l}\text { 12. Total Subtraction-Method X-tax } \\
\text { Collections }\end{array}$ & $\$ 6$ & $\$ 10.50$ & $\$ 6$ & $\$ 22.50$ \\
\hline \multicolumn{5}{|l|}{ Credit-Method X-tax } \\
\hline $\begin{array}{l}\text { 12. VAT assessed on sales } \\
(30 \% \text { of line } 1)\end{array}$ & $\$ 9$ & $\$ 21$ & $\$ 30$ & \\
\hline 13. Less: input tax on purchases & $\$ 0$ & $\$ 9$ & $\$ 21$ & \\
\hline 14. VAT liability & $\$ 9$ & $\$ 12$ & $\$ 9$ & $\$ 30$ \\
\hline $\begin{array}{l}\text { 15a. Wage tax }(X-\text { tax paid at } \\
\text { individual level) lower bracket } \\
(15 \% \text { of line } 3 a)\end{array}$ & $\$ 3$ & $\$ 1.50$ & $\$ 3$ & $\$ 7.50$ \\
\hline $\begin{array}{l}\text { 15b. Wage tax }(\mathrm{X} \text {-tax paid at } \\
\text { individual level) higher } \\
\text { bracket }(30 \% \text { of line } 3 \mathrm{~b})\end{array}$ & $\$ 0$ & $\$ 3$ & $\$ 1.80$ & $\$ 4.80$ \\
\hline $\begin{array}{l}\text { 16. Total VAT + wage tax } \\
\text { (credit-method X-tax) } \\
\text { collection }\end{array}$ & $\$ 12$ & $\$ 16.50$ & $\$ 13.80$ & $\$ 42.30$ \\
\hline $\begin{array}{l}\text { 17. Less: "American Jobs Credit" } \\
(30 \% \text { of lines } 3 a+3 b)\end{array}$ & $\$ 6$ & $\$ 6$ & $\$ 7.80$ & \\
\hline $\begin{array}{l}\text { 18. Total "credit-method X-tax" } \\
\text { liability }\end{array}$ & $\$ 6$ & $\$ 10.50$ & $\$ 6$ & $\$ 22.50$ \\
\hline
\end{tabular}

instruments for the promotion of social and economic policy objectives" (GATT, 1973). Jobs subsidies programs currently in use or previously used by other OECD countries that are somewhat narrower but otherwise similar to the AJC have never been challenged at the WTO. ${ }^{57}$

\section{"Substance over Form" Arguments}

Some observers argue that a uniformly available employment support payment would lead the WTO to "look through" the form and conclude that as a matter of substance the AJC mimics the effect of the deduction for wages in a subtrac-

57 Germany, for example, has a series of "active labor" programs that typically take the form of direct subsidies to employers; amounts provided are calculated as a percentage of total salary costs (Human Resource and Skills Development Canada, 1994). Other countries similarly use wage subsidies that are available on a non-discriminatory basis but target workers in a specific sector. None of these programs has been challenged at the WTO. 
tion-method X-tax and, therefore, is not compliant with the GATT/WTO (Merrill, 2006). However, because the direct/indirect distinction lacks economic substance, it can only be applied in a formalistic manner. ${ }^{58}$ Were the AJC cash subsidy to convert a credit-method VAT from an indirect tax to a direct tax that is not border-adjustable, then European wage subsidy programs that similarly provide support to businesses would also be suspect.

One can also imagine credit-method $\mathrm{X}$-tax border adjustments being challenged on the grounds that in substance they provide an "exemption or remission" of tax in excess of the tax imposed on like products when sold for domestic consumption.

TABLE 6

EXAMPLE 6: SUBTRACTION-METHOD VAT, CREDIT-METHOD VAT, SUBTRACTION-METHOD X-TAX, AND CREDIT-METHOD X-TAX WITH EXPORTS

\begin{tabular}{|c|c|c|c|c|}
\hline Economic Activity & Farmer & Brewer & Beer Exporter & Total \\
\hline \multicolumn{5}{|l|}{ Basic transactions } \\
\hline 1. Sales & $\$ 30$ & $\$ 70$ & \$ 100 (zero-rated) & \\
\hline 2. Purchases & $\$ 0$ & $\$ 30$ & $\$ 70$ & \\
\hline 3a. Lower-bracket labor & $\$ 20$ & $\$ 10$ & $\$ 20$ & \\
\hline 3b. Higher-bracket labor & $\$ 0$ & $\$ 10$ & $\$ 6$ & \\
\hline 4. Value added (sales - purchases) & $\$ 30$ & $\$ 40$ & $-\$ 70$ & $\$ 100$ \\
\hline \multicolumn{5}{|l|}{ Subtraction-Method VAT } \\
\hline $\begin{array}{l}\text { 5. Subtraction-method VAT } \\
(30 \% \text { of line } 4)\end{array}$ & $\$ 9$ & $\$ 12$ & $-\$ 21^{*}$ & $\$ 0$ \\
\hline \multicolumn{5}{|l|}{ Credit-Method VAT } \\
\hline 6. Tax on sales $(30 \%$ of line 1$)$ & $\$ 9$ & $\$ 21$ & $\$ 0$ (zero-rated) & \\
\hline 7. Less: input tax on purchases & $\$ 0$ & $\$ 9$ & $\$ 21^{*}$ & \\
\hline 8. Net VAT liability & $\$ 9$ & $\$ 12$ & $-\$ 21$ & $\$ 0$ \\
\hline \multicolumn{5}{|l|}{ Subtraction-Method X-tax } \\
\hline $\begin{array}{l}\text { 9. Tax paid at business level } \\
(30 \% \text { of line } 4-\text { line } 3 a-\text { line } 3 b)\end{array}$ & $\$ 3$ & $\$ 6$ & $-\$ 28.80 * ?$ & $-\$ 19.80$ \\
\hline $\begin{array}{l}\text { 10. Tax paid at individual level- } \\
\text { lower bracket ( } 15 \% \text { of line } 3 a)\end{array}$ & $\$ 3$ & $\$ 1.50$ & $\$ 3$ & $\$ 7.50$ \\
\hline $\begin{array}{l}\text { 11. Tax paid at individual level- } \\
\text { higher bracket ( } 30 \% \text { of line } 3 \mathrm{~b})\end{array}$ & $\$ 0$ & $\$ 3$ & $\$ 1.80$ & $\$ 4.80$ \\
\hline 12. Total subtraction-method X-tax & $\$ 6$ & $\$ 10.50$ & $-\$ 24$ & $-\$ 7.50$ \\
\hline \multicolumn{5}{|l|}{ Credit-Method X-tax } \\
\hline 12. VAT assessed on sales ( $30 \%$ of line 1 ) & $\$ 9$ & $\$ 21$ & $\$ 0$ (zero-rated) & \\
\hline 13. Less: input tax on purchases & $\$ 0$ & $\$ 9$ & $\$ 21^{*}$ & \\
\hline 14. VAT liability & $\$ 9$ & $\$ 12$ & $-\$ 21$ & $\$ 0$ \\
\hline $\begin{array}{l}\text { 15a. Wage tax (X-tax paid at individual level) } \\
\text { lower bracket }(15 \% \text { of line } 3 a)\end{array}$ & $\$ 3$ & $\$ 1.50$ & $\$ 3$ & $\$ 7.50$ \\
\hline $\begin{array}{l}\text { 15b. Wage tax (X-tax paid at individual level) } \\
\text { higher bracket ( } 30 \% \text { of line } 3 \mathrm{~b})\end{array}$ & $\$ 0$ & $\$ 3$ & $\$ 1.80$ & $\$ 4.80$ \\
\hline $\begin{array}{l}\text { 16. Total VAT + wage tax } \\
\text { (credit-method X-tax) collection }\end{array}$ & $\$ 12$ & $\$ 16.50$ & $-\$ 16.20$ & $\$ 12.30$ \\
\hline $\begin{array}{l}\text { 17. Less: "American Jobs Credit" } \\
(30 \% \text { of lines } 3 a+3 b)\end{array}$ & $\$ 6$ & $\$ 6$ & $\$ 7.80$ & \\
\hline 18. Total "credit-method X-tax" liability & $\$ 6$ & $\$ 10.50$ & $-\$ 24$ & $-\$ 7.50$ \\
\hline
\end{tabular}

*Border adjustment.

58 Economists have long disputed the incidence of the corporate tax, and in a global economy there are also disputes about the incidence of VAT. Perhaps the application of WTO distinctions between direct and indirect taxes would be less formalistic if economists could provide greater certainty regarding economic incidence questions. One recent analysis of the incidence of the corporate tax suggests that it may largely be borne by labor (Randolph, 2006); another important contribution highlights ways in which the ultimate incidence of the tax remains unresolved. 
The $\$ 28.80$ in total payments the exporter receives from the government under a credit-method X-tax (line $14+$ line 17) is the same amount that would be received through a subtraction-method X-tax border adjustment (line 9). As such, it could be claimed that the credit-method X-tax provides excess remission of tax and should receive the same treatment under WTO rules as a subtraction-method X-tax.

However, the same arguments that suggest the AJC is permissible under WTO rules suggest the AJC cannot be taken into account in determining whether there is excess remission of a tax. Labor subsidies are not treated as part of the tax system for WTO purposes. ${ }^{59}$ Again, the parallel to European wage subsidy programs applies. Those programs, when combined with a border adjustment, produce an overall tax plus wage subsidy net rebate on exported products.

\section{OTHER ALTERNATIVES}

The Tax Reform Panel indicated that they chose the subtraction-method X-tax in order to gain the benefits of a consumption tax while maintaining the progressivity of the status quo. As discussed above, this result can also be achieved using a credit-method $X$-tax that allows for superior administration and enforcement. However, the credit-method X-tax is only one of many WTO-compliant alternatives if the goal is to improve the progressivity of a consumption tax. Cash payments to individuals, "e-cards," a payroll tax rebate (such as that proposed by Graetz), VAT tax credits, ${ }^{60}$ or other demigrants can all improve the progressivity of a credit-method VAT (Graetz, 2002). These alternatives could each produce distributional results that are similar to any $\mathrm{X}$-tax variant, and each may be politically appealing to policymakers.

An important difference between the consumption tax systems described in this article and VATs used in the rest of the developed world is that the latter sit alongside income taxes, whereas the tax systems considered here would replace the income tax. ${ }^{61}$ Although beyond the scope of this article, the existence of an income tax alongside a consumption tax may reduce certain incentives for evasion or avoidance of a consumption tax. For instance, the higher rate required to fully replace the income tax might encourage greater tax evasion. The existence of a national income tax alongside a national VAT may also have other salutary effects for tax administration and enforcement. For example, data collected for purposes of enforcing the VAT may help with income tax enforcement, and vice versa. These issues are important areas for further study if an X-tax were to receive serious consideration by policymakers. A credit-method VAT alongside a reduced income tax may be better than any "one tax" system.

\section{CONCLUSION}

The credit-method X-tax and the subtraction-method $\mathrm{X}$-tax are two similar ways of taxing consumption. Both taxes can be made progressive, and with proper calibration the level of progressivity implied by one tax regime can be recreated in the

59 GATT historically resisted explicitly addressing labor policies. For example, the U.S. request to link flexible labor rules and free trade in a ministers' declaration made at the time of formation of the WTO was rebuffed (Riding, 1994). Further, when linkages were explored, the question was whether labor standards and wage supports were sufficiently high, and not whether a country was providing excessive wage supports (Alben, 2001).

60 Canada uses such a credit to make its Goods and Services Tax (a credit-method VAT) more progressive (Mitchell and Shillington, 2004).

61 Special enforcement problems would arise were a residual tax on capital income only retained alongside an X-tax. The Tax Reform Panel's Growth and Investment Tax recommendation included such a tax at a rate of 15 percent on interest, dividends, and capital gains. 
other. However, it could be politically difficult to adapt credit-method best practices such as those associated with information collection, small businesses, and losses to a subtraction-method system. Further, the mechanisms used to make the subtractionmethod $X$-tax progressive are problematic under WTO rules. A subtraction-method $\mathrm{X}$-tax cannot be administered on a destination basis and remain WTO-compliant. A destination-basis consumption tax is strongly preferable to an origin-basis consumption tax from an administration and enforcement perspective. In contrast, a progressive consumption tax system based on a credit-method VAT, such as the credit-method X-tax, can simultaneously be imposed on a destination basis and comply with current WTO rules.

Thus, even if policymakers' desired distributional outcomes matched the distribution of the tax burden produced by a variant of the subtraction-method X-tax, it would be preferable to achieve that result using a system based on a credit-method VAT. Depending on the distributional results policymakers wished to achieve, one appropriate mechanism for providing progressivity to the VAT could be the credit-method X-tax outlined here, utilizing an appropriate business-level wage subsidy and a tax on wages.

The academic literature has given insufficient attention to political and administrative realities in weighing the costs and benefits of a subtraction-method X-tax as compared to a credit-method-based system. This article describes some of the issues and offers one proposal to maintain progressivity, avoid the WTO compliance and tax enforcement paradox, and retain the practical advantages of the creditmethod system. Continued work in this area would be of benefit to the literature.

\section{Acknowledgments}

A number of friends and colleagues generously took the time to read and provide comments on this article. I thank Lily Batchelder, Fred Goldberg, Michael Graetz, Pamela Olson, and Paul Oosterhuis for their thoughts and advice. A working group within the President's Advisory Panel on Federal Tax Reform also considered some of the issues discussed herein. I thank Bill Gentry, Eddie Lazear, Jim Poterba, David Weisbach, and most especially Rosanne Altshuler for those discussions. I would also like to thank Skadden, Arps, Slate, Meagher \& Flom LLP for its support of this project. Any errors or omissions are my own.

\section{REFERENCES}

Alben, Elissa.

"GATT and the Fair Wage: A Historical Perspective on the Labor-Trade Link." Columbia Law Review 101 No. 6 (October, 2001): 1410-47.

Andrews, William D.

"A Consumption-Type or Cash Flow Personal Income Tax." Harvard Law Review 87 No. 6 (April, 1974): 1113-88.

Atkinson, A.B.

"The Distribution of the Tax Burden." In Modern Public Finance, edited by Joseph J. Cordes, 282. Cambridge, MA: Harvard University Press, 2004.

Auerbach, Alan J.

"The Future of Fundamental Tax Reform." American Economic Review 87 No. 2 (May, 1997): 143-6.

Auerbach, Alan J.

"Who Bears the Corporate Tax? A Review of What We Know." Tax Policy and the Economy 20 (2006): 1-40.

Bankman, Joseph, and Michael Schler.

"Tax Planning Under the Flat Tax/X-Tax." Paper prepared for Brookings Institution Conference on Taxing Capital Income: Do We? Should We? Can We? (Can We Not?). Washington, D.C., September, 2005.

Bradford, David F.

Fundamental Issues in Consumption Taxation. Washington, D.C.: AEI Press, 1996. 
Bradford, David F.,

"Blueprint for International Tax Reform." Brooklyn Journal of International Law 26 No. 4 (2001): 1449-63.

Bradford, David F.

"The X-Tax in the World Economy." NBER Working Paper No. 10676. Cambridge, MA: National Bureau of Economic Research, 2004.

Bradford, David F.

"A Tax System for the $21^{\text {st }}$ Century." In Towards Fundamental Tax Reform, edited by Alan J. Auerbach, 13. Washington, D.C.: AEI Press, 2005.

Cardin, Benjamin L.

Cardin Introduces Bipartisan Legislation to Extend and Make Permanent the RED Tax Credit. 2005 TNT 76-39, April 21, 2005. Available in LEXIS, TNT File.

Ebrill, Liam, Michael Keen, Jean-Paul Bodin, and Victoria Summers.

The Modern VAT. Washington, D.C.: International Monetary Fund, 2001.

Fuchs, Victor, Alan B. Krueger, and James M. Poterba.

"Economists' Views about Parameters, Values, and Policies: Survey Results in Labor and Public Economics." Journal of Economic Literature 36 No. 3 (September, 1998): 1387-425.

General Agreements on Tariffs and Trade (GATT).

Border Tax Adjustments - Report of the Working Party, L/3464 (December 2, 1970). In GATT, Basic Instruments and Selected Documents, 18th Supplement, BISD §18S/97-109. April, 1972.

GATT.

Agreement on Interpretation and Application of Articles VI, XVI, and XXIII of the General Agreement on Tariffs and Trade. September 12, 1973.

Gibbons, Samuel.

Testimony before U.S. House of Representatives, Subcommittee on Select Revenue Measures of the Committee on Ways and Means. Washington, D.C., April, 20, 2002.

Goldberg, Daniel S.

"E-Tax: Fundamental Tax Reform and the Transition to a Currency-Free Econo- my." Virginia Tax Review 20 No. 1 (Summer, 2000): 7.

Graetz, Michael.

"International Aspects of Fundamental Tax Restructuring: Practice or Principle?" University of Miami Law Review 51 (July, 1997): 1093-107.

Graetz, Michael, and Paul Oosterhuis.

"Structuring an Exemption System for Foreign Income of U.S. Corporations." $\mathrm{Na}$ tional Tax Journal 54 No. 4 (December, 2001): 771-86.

Graetz, Michael.

"100 Million Unnecessary Returns: A Fresh Start for the U.S. Tax System." Yale Law Journal 112 No. 2 (November, 2002): 261310.

Grubert, Harry, and T. Scott Newlon.

"The International Implications of Consumption Tax Proposals." National Tax Journal 48 No. 4. (December, 1995): 619-47.

Halifax PLC and Others v. Commissioners of

Customs and Excise.

Decision No. 17124, VAT \& Duties Tribunal (March 1, 2001) and STC 402 (Ch.D) [2002]. Halifax and Others v. Customs and Excise Commissioners.

Case C-255/02, European Court of Justice (February 21, 2006).

Hall, Robert E., and Alvin Rabushka.

The Flat Tax. Stanford: Hoover Institution Press (2 ${ }^{\text {nd }}$ Edition $), 1995$.

Hall, Robert E.

"Guidelines For Tax Reform: The Simple, Progressive Value-Added Consumption Tax." In Toward Fundamental Tax Reform, edited by Alan J. Auerbach and Kevin A. Hassett, 70-80. Washington, D.C.: AEI Press, 2005.

Hall, Robert E.

"The Flat Tax and the X-Tax." Presentation to the Tax Reform Panel, Hoover Institution. May 11, 2005.

Hamilton, Alexander, James Madison, and John Jay.

The Federalist Papers. New York: Penguin Books, 1961.

Hufbauer, Gary Clyde, and Paul L.E. Grieco. "Comprehensive Reform for US Business Taxation: Statement to the US-China Eco- 
nomic and Security Review Commission, China and the Future of Globalization." May 20, 2005. http:/ /www.uscc.gov/hearings/ 2005hearings/written_testimonies/05_05_ 19_20wrts/hufbauer_gary_wrts.pdf.

Human Resources and Skills Development Canada.

Wage Subsidies to Encourage the Hiring of Unemployment Insurance Claimants. November, 1994. http://www11.hrsdc. gc.ca/en/cs/sp/hrsdc/arb/publications/ research/1998-000026/1998-000026E.pdf.

Japanese Ministry of Finance, Tax Bureau. An Outline of Japanese Taxes. Tokyo, Japan: 2005.

Keen, Michael, and Stephen Smith.

"VAT Fraud and Evasion: What Do We Know and What Can Be Done?" National Tax Journal 59 No. 4 (December, 2006): 861-88.

Kerry, John, and John Edwards.

Our Plan for America: Stronger at Home, Respected in the World. New York: Perseus Book Group, 2004.

McCaffery, Edward J.

Fair Not Flat: How to Make the Tax System Simpler and Better. Chicago: University of Chicago Press, 2002.

McLure, Charles E.

"The U.S. Debate on Consumption-Based Taxes: Implications for the Americas." University of Miami Inter-American Law Review 29 (Fall, 1997/Winter, 1998): 143-96.

McLure, Charles E.

"The Value-Added Tax (VAT)." Presentation to the Tax Reform Panel, Hoover Institution. May 11, 2005.

Merrill, Peter.

"VAT and Other Consumption Taxes." Panel Comments at the ABA Tax Section February 2006 Mid-Year Meeting. San Diego, CA, February 4, 2006.

Mikesell, John L.

"A Quality Index for State Sales Tax Structure-Measuring the States Against an Ideal Standard." State Tax Notes 35 No. 2 (January 10, 2005): 129-36.

Mitchell, Andrew, and Richard Shillington.

"Federal Tax Relief for Low Income People." Discussion paper prepared for the $\mathrm{Na}$ - tional Anti-Poverty Organization. Ottawa, Canada, November, 2004. http://www. napo-onap.ca/en/issues/tax_cuts.php.

Morrison, Phil.

"Viewpoint, Why Tax Reform Panel's 'GIT' Proposal Will Soon be Gone." BNA Daily Tax Report No. 32 (February 16, 2006): J-1.

Nias, Peter, and Amy Manchia.

"Halifax Judgment Raises VAT Planning Questions." Tax Notes International 42 No. 1 (April 3, 2006): 7.

Owens, Jeffrey.

"Fundamental Tax Reform: An International Perspective." National Tax Journal 59 No. 1 (March, 2006): 131-64.

Pearlman, Ronald A.

"A Tax Reform Caveat: In the Real World, There Is No Perfect Tax System." In Toward Fundamental Tax Reform, edited by Alan J. Auerbach and Kevin Hassett, 106-22. Washington, D.C.: AEI Press, 2005.

President's Advisory Panel on Federal Tax Reform (Tax Reform Panel).

Simple, Fair, and Pro-Growth: Proposals to Fix America's Tax System. Final Report of the Advisory Panel. Washington, D.C.: Government Printing Office, November, 2005.

Price, David E.

Earned Income Tax Credit. 93 TNT 168-56, August 12, 1993. Available in LEXIS, TNT File.

Randolph, William C.

"International Burdens of the Corporate Income Tax." CBO Working Paper No. 2000-09. Washington, D.C.: Congressional Budget Office, 2006.

R\&D Credit Coalition.

Letter to Congressmen Bill Thomas, Charles Grassley, Charlie Rangel, and Max Baucus. March, 2003. http://www.bio.org/tax/ r\&d/20030300.asp.

Riding, Alan.

"U.S. Gains a Trade Forum for Labor-Equity Issues." New York Times (April 8, 1994): D6.

Rosen, Harvey S.

Public Finance. Boston: McGraw-Hill-Irwin ( $7^{\text {th }}$ Edition), 2004.

Schenk, Alan.

"Japanese Consumption Tax After Six Years: A Unique VAT Matures." Tax Notes 
International 11 No. 21 (November 20, 1995): 1379-93.

Shaviro, Daniel N.

"Simplifying Assumptions: How Might the Politics of Consumption Tax Reform Affect (Impair) the End Product?" NYU, Law and Economics Research Paper No. 06-17. New York: New York University, April, 2006.

Summers, Victoria P.

"The Border Adjustability of Consumption Taxes, Existing and Proposed." Tax Notes International 12 No. 23 (June 3, 1996): 1993.

Thuronyi, Victor.

Comparative Tax Law. Wolters Kluwer Law and Business: Aspen Publishers, 2003.

United States v. State of West Virginia, 339 F.3d

212 (4th Cir. 2003).

U.S. Congress. Senate.

Omnibus Reconciliation Act of 1993. 103 ${ }^{\text {rd }}$

Cong., 1st sess., 1993. P.L. 103-66.

U.S. Government Accountability Office (GAO). Tax Policy: Value-Added Tax-Implications of Replacing the Corporate Income Tax with a Consumption Tax. Washington, D.C., 1993.

Ventry, Dennis J.

"The Collision of Tax and Welfare Politics: The Political History of the Earned Income Tax Credit." National Tax Journal 53 No. 4 (December, 2000): 1969-99.

Viard, Alan.

"Border Adjustments Won't Promote Competitiveness." Tax Notes International 36 No.

2 (October 11, 2004): 159.

Weisbach, David.

"Ironing Out the Flat Tax." Stanford Law Review 52 (February, 2000): 599-664.

Weisbach, David.

"Does the X-Tax Mark the Spot?" SMU Law Review 56 (2003): 201-38.

World Trade Organization (WTO).

Agreement on Subsidies and Countervailing Measures. Geneva, Switzerland, April 15, 1994.

Zenith Radio Corp. v. United States, 437 U.S. 443, 446 (1978). 